EASTERN REVIEW 2016, T. 5

\author{
Grzegorz Janusz
}

\title{
Bezpieczeństwo regionalne w kontekście rzekomego naruszania praw ludności rosyjskiej na Ukrainie oraz mechanizmów europejskiego systemu ochrony praw mniejszości
}

W kontekście działań inspirowanych i popieranych przez Rosję na wschodzie Ukrainy, a skierowanych także na obronę rzekomo naruszanych praw ludności rosyjskojęzycznej na Krymie i we wschodnich obwodach Ukrainy, warto odnieść się do tej kwestii w kontekście legalnych, z punktu widzenia prawa międzynarodowego, działań związanych z ochroną praw mniejszościowych, a także ewentualnego naruszenia bezpieczeństwa regionalnego.

Naruszanie praw mniejszości językowej (narodowej) i reakcja na to zjawisko państwa, z którym ta mniejszość czuje się związana etnicznie i kulturowo, nie jest niczym nowym w stosunkach międzynarodowych. Zasadniczo należy wyraźnie rozróżnić trzy kwestie:

1) potencjalne lub realne naruszenie praw mniejszości narodowej;

2) reakcję państwa, z którym ta mniejszość czuje się związana etnicznie i kulturowo;

3) mechanizmy możliwej ochrony praw mniejszości.

Sytuacja ludności rosyjskiej na całej Ukrainie, a zwłaszcza w obwodach wschodnich, wynika przede wszystkim z utraty statusu narodu większościowego, określanego w języku rosyjskim i angielskim jako naród tytularny (титульная нациия, titular nation), a w języku niemieckim jako naród państwowy lub panujący (Staatsvolk, Herrenvolk). Z chwilą powstania niepodległego państwa ukraińskiego ludność rosyjska, należąca do narodu większościowego, utraciła swój status i znalazła się w mało komfortowej sytuacji mniejszości narodowej. Co prawda, ze względu na więzi kulturowe, po części rodzinne, religijne, historyczne i językowe, status tej ludności odbiegał od sytuacji, w jakiej znalazły się np. mniejszości niemieckie czy węgierskie po pierwszej wojnie światowej. Zwłaszcza na terenie wschodniej Ukrainy istniały regiony, gdzie nie działała np. żadna szkoła 
ukraińska, a w powszechnym użyciu był język rosyjski ${ }^{1}$. Jedynym dyskomfortem dla dużej części ludności rosyjskiej na Ukrainie, obok zamieszkiwania w innym państwie, był fakt, że język rosyjski nie był drugim językiem urzędowym, aczkolwiek faktycznie taki status język ten miał, zwłaszcza we wschodnich obwodach. Jednocześnie, zgodnie z Konstytucją Ukrainy, określającą w art. 10, że język ukraiński jest językiem państwowym, wskazywano w art. 10 akapit 3, że: „Na Ukrainie gwarantuje się swobodny rozwój, używanie i ochronę języka rosyjskiego oraz innych języków mniejszości narodowych Ukrainy"'. Wyróżnienie języka rosyjskiego nie było przypadkowe, gdyż wynikało z faktycznego znaczenia tego języka w stosunkach społecznych na Ukrainie.

W odniesieniu do reakcji Rosji na przełomie lutego i marca 2014 r., zwłaszcza po ucieczce byłego prezydenta Ukrainy Wiktora Janukowicza, należy podkreślić pojawienie się argumentu konieczności ochrony rzekomo naruszanych praw ludności rosyjskiej na terenie Autonomicznej Republiki Krymu, a tym samym uzasadnienie wsparcia dla irredentyzmu krymskiego ${ }^{3}$. Sam argument o ochronie praw ludności rosyjskiej podniesiony został także przez Rosję w kwietniu 2014 r. już po rozpoczęciu działań zbrojnych przez prorosyjskie ugrupowania na terenie obwodów donbaskiego i ługańskiego, a bardzo szybko wyeliminowano go z oficjalnych wypowiedzi polityków i władz Rosji. Być może przyczyną były pojawiające się w owym czasie porównania polityki Rosji wobec Ukrainy do działań władz III Rzeszy wobec Czechosłowacji i wsparcia irredentyzmu Niemców Sudeckich w 1938 r. Niezależnie od przyczyn rezygnacji z takiej argumentacji należy pod-

${ }^{1}$ Część studiujących w Polsce studentów narodowości ukraińskiej, pochodzących ze wschodnich obwodów Ukrainy, dopiero w Polsce, w kontaktach z innymi studentami ukraińskimi, nabywała znajomość języka ukraińskiego i umiejętność posługiwania się nim. Taki stan rzeczy wynikał z faktycznego używania na terenie ich zamieszkiwania języka rosyjskiego oraz braku szkół $\mathrm{z}$ ukraińskim językiem nauczania.

${ }^{2}$ Конституиія України, Відомості Верховної Ради Украӥни, (Із змінами, внесеними згідно із Законами), 1996, по. 30, s. 141.

${ }^{3} \mathrm{Na}$ Krymie nie mieliśmy do czynienia z działaniami separatystycznymi, jak mylnie je określano zarówno $\mathrm{w}$ mass mediach, jak i wypowiedziach polityków, ale z irredentą. $\mathrm{W}$ przypadku separatyzmu mamy do czynienia $\mathrm{z}$ dążeniem do utworzenia samodzielnego bytu państwowego. Natomiast celem irredenty jest oderwanie danego terytorium od jednego państwa celem przyłączenia go do innego państwa. Biorąc pod uwagę zachodzące na Krymie procesy, nie ulega wątpliwości, że tzw. separatyzm krymski był wyłącznie pretekstem do irredenty: 17 marca 2014 r. Rada Najwyższa Autonomicznej Republiki Krymu ogłosiła niepodległość Krymu, a 18 marca 2014 r. podjęła decyzję o przyłączeniu się do Rosji. Natomiast 21 marca dokonano zmian w Konstytucji Rosji, dopisując dwa podmioty: Republikę Krymu i miasto Sewastopol (por. Федеральный конституционный закон „О принятии в Российскую Федераџию Республики Крым и образовании в составе Российской Федерации новых субъектов - Республики Крым и города федерального значения Севастополя", одобренному Государственной Думой 20 марта 2014 года, Советом Федерации 21 марта 2014 год). Takich szybkich zmian proceduralnych współczesna Europa jeszcze nie znała. 
kreślić, że tworzenie i popieranie przez dane państwo ugrupowań zbrojnych na terytorium innego państwa pod pretekstem ochrony praw określonej grupy ludności stanowi we współczesnych stosunkach międzynarodowych anachronizm. Z taką sytuacją we współczesnej Europie nie mieliśmy do czynienia. Podjęte przez Rosję działania skutkowały natomiast bardzo realnym zagrożeniem bezpieczeństwa regionalnego, którego skutki odnoszą się nie tylko do relacji Ukraina - Rosja.

Motywację dla działań Rosji wobec Ukrainy odnaleźć można w wypowiedzi prezydenta Rosji W. Putina dla Radia Europa 1 oraz Telewizji TF1 z 4 czerwca 2014 r., gdzie prezydent Rosji stwierdził, że: „Rozpad Związku Radzieckiego był jedną z największych katastrof humanitarnych, humanitarnych przede wszystkim, katastrof XX wieku. W ramach Związku Radzieckiego wszyscy obywatele bez względu na etniczną przynależność mieszkali w jednym państwie, a po rozpadzie ZSRR 25 milionów rosyjskich ludzi niespodziewanie dla siebie znalazło się za granicą"4. Odnosząc się do kwestii wojny prowadzonej we wschodnich obwodach Ukrainy, stwierdził, że nie ma na obszarze konfliktu sił prorosyjskich i „Jeśli są ludzie, którzy mają określone prawa - prawa polityczne, humanitarne, to oni powinni mieć możliwość te prawa realizować. Po tym, jak dokonał się niekonstytucyjny przewrót w Kijowie w lutym tego roku, pierwszym, co dokonały nowe władze - oświadczyły o zniesieniu praw mniejszości narodowych w zakresie używania języka ojczystego"s.

W tym zakresie prezydent Rosji się mylił, gdyż ta ustawa obowiązywała nadal. Podkreślić należy, że ustawa o podstawach polityki językowej z 10 lipca 2012 r., zwana też ustawą Kołesniczenki-Kiwałowa ${ }^{6}$, wprowadzała nowe pojęcie języka regionalnego. W odczuciu ówczesnej opozycji była narzędziem wzmacniającym status ludności rosyjskojęzycznej i stanowiła także element przygotowań obozu rządzącego do jesiennych wyborów parlamentarnych. Zarzucano, że przy jej uchwalaniu doszło do naruszenie procedur legislacyjnych, w tym brak było wymaganej większości głosów do uchwalenia tej ustawy. Sama ustawa, w wyniku nowej sytuacji politycznej, została co prawda uchylona ustawą Rady Najwyższej z 23 lutego 2014 r., jednakże do dnia dzisiejszego nie została ona podpisana przez prezydenta Ukrainy, a ustawa językowa zachowuje swoją moc. Należy podkreślić, że ustawa jest zgodna z treścią ratyfikowanej w 2005 r. Europejskiej Karty języków regionalnych lub mniejszościowych, która wobec Ukrainy weszła w życie z dniem 1 stycznia 2006 r. $^{7}$

${ }^{4}$ Интервью Владимира Путина радио «Европа-1» и телеканалу TFl (http://www.kremlin.ru/news/45832) (05.11.2014).

5 Ibidem.

6 Закон України, Про засади державної мовної політики („Відомості Верховної Ради” 2013, № 23, s. 218).

${ }^{7} \mathrm{http}: / /$ conventions.coe.int/Treaty/Commun/ChercheSig.asp?NT $=148 \& \mathrm{CM}=8 \& \mathrm{DF}=\& \mathrm{C}-$ $\mathrm{L}=\mathrm{ENG}(28.11 .2016)$. 
Dość charakterystyczna była jednocześnie ocena samego przyłączenia Krymu do Rosji, gdyż Putin wprost potwierdził uczestnictwo wojsk rosyjskich w zajęciu Krymu i doprowadzeniu do oderwania półwyspu od Ukrainy ${ }^{8}$. Dość interesujące było odwołanie się do prawa narodów do samostanowienia i Karty Narodów Zjednoczonych. Rzeczywiście art. 1 ust. 2 Karty NZ określa, że Narody Zjednoczone dążą: „do rozwoju przyjaznych stosunków pomiędzy narodami, opartych na poszanowaniu zasady równouprawnienia i stanowienia narodów o sobie", ale chyba zapomniał o zasadzie wyrażonej w ust. 1 tegoż artykułu, że cele te będą państwa-strony Karty „osiągały, przy pomocy środków pokojowych i zgodnie z zasadami sprawiedliwości i prawa międzynarodowego, załatwianie lub rozstrzyganie sporów międzynarodowych"”.

Samo odwołanie się do prawa narodów do samostanowienia, dość enigmatycznie wskazanego w Karcie NZ, wymaga jednak bliższego wyjaśnienia. Pojawiło się ono także w art. 1 ust. 1 Międzynarodowego Paktu Praw Obywatelskich i Politycznych z 19 grudnia 1966 r., w którym określono, że: „wszystkie narody mają prawo do samostanowienia. $Z$ mocy tego prawa swobodnie określają one swój status polityczny i swobodnie zapewniają swój rozwój gospodarczy, społeczny i kulturalny" ${ }^{\prime 10}$. Zasada prawa narodów do samostanowienia w praktyce jest mało realną w realizacji, gdyż trudno oczekiwać, że aspiracje każdej społeczności etnicznej spowodują powstanie własnego państwa. Prawo do interpretacji przepisów Międzynarodowego Paktu Praw Obywatelskich i Politycznych posiada Komitet Praw Człowieka (Human Rights Committee - HRC) utworzony w 1976 r. na podstawie art. 28 Paktu, czyniąc to poprzez przyjmowanie opinii generalnej. Do interesującej nas kwestii Komitet odniósł się w opinii generalnej nr 12 O prawie samostanowienia narodów, która przyjęta została 13 marca 1984 r. na 21. sesji Komitetu ${ }^{11}$. Punktem wyjścia było uznanie, że „Prawo samostanowienia jest szczególnego znaczenia, ponieważ jego realizacja jest istotnym warunkiem dla

8 Так вот, российские войска находились в Крыму в соответствии с международным договором о наличии там российской военной базы. И российские войска действительно помогли жителям Крыма провести референдум о своей независимости и желании присоединиться к Российской Федерачии. И никто не имеет права отказать этим людям в том, чтобы они реализовали право, предусмотренное статьёй первой Устава Организации Объединённых Наций, - право наций на самоопределение, Интервью Владимира Путина радио „Европа-1” и телеканалу TF1 (http://www.kremlin.ru/news/45832 (28.11.2016).

${ }^{9}$ Karta Narodów Zjednoczonych. Statut Międzynarodowego Trybunału Sprawiedliwości i Porozumienie ustanawiajace Komisję Przygotowawcza Narodów Zjednoczonych, „Dziennik Ustaw” 1947, nr 23, poz. 90.

${ }^{10}$ Międzynarodowy Pakt Praw Obywatelskich i Politycznych otwarty do podpisu w Nowym Jorku dnia 19 grudnia 1966 r., „Dziennik Ustaw” 1977, nr 38, poz. 167 zał.

${ }^{11}$ General Comment No. 12: The right to self-determination of peoples (Art. 1), 13.03.84, (http://www.unhchr.ch/tbs/doc.nsf/(Symbol)/f3c99406d528f37fc12563ed004960b4?Opendocument (27.11.2016). 
efektywnej gwarancji i przestrzegania indywidualnych praw człowieka i dla promowania i wzmacniania tych praw" (pkt 1 opinii). Jednocześnie z tekstu opinii wynika, że Komitet zdawał sobie sprawę z trudności w realizacji prawa narodów do samostanowienia i opowiadał się nie tyle za realną możliwością skorzystania z tego prawa przez każdą społeczność etniczną zamieszkałą w państwie, co za stworzeniem przez władze państwowe warunków do rozwijania samorządności wśród tych ludów, które nie były w stanie skorzystać lub są pozbawione możliwości skorzystania z prawa do samostanowienia. W opinii wskazano na obowiązek państwa wspierania takich ludów, czyli tych zbiorowości, które mają status mniejszościowy. Zastrzeżono jednakże wyraźnie, że państwa winny powstrzymać się od ingerowania w sprawy wewnętrzne innych państw i tym samym wpływać na realizację prawa do samostanowienia. Jednocześnie widoczne jest wyraźne adresowanie tego prawa do grup etnicznych o charakterze autotelicznym, czyli nie stanowiących odłamu innego narodu. Powstaje w tej sytuacji pytanie, jaką odrębną narodowość tworzą Rosjanie na Krymie lub w obwodach donieckim i ługańskim?

Jest oczywiste, że państwa mają prawo interesować się sytuacją oraz statusem zamieszkałej w innym państwie grupy ludności, która wyraża z nim więzi etniczno-kulturowe. Należy podkreślić, że oficjalna reakcja Rosji miała charakter a priori, tzn. zjawisko naruszenia praw ludności rosyjskiej na Ukrainie nie wystąpiło, a działania podjęto, wskazując wyłącznie na możliwość potencjalnego naruszenia takich praw. Jednocześnie z przepisów prawa międzynarodowego wynika wyraźne ograniczenie możliwości użycia własnych wojsk do ingerencji w sprawy innego państwa, także dla obrony rzeczywiście, czy tylko domniemanie naruszonych praw mniejszości identyfikującej się z tym państwem. Nie daje takiego upoważnienia do ingerowania poprzez własne oddziały wojskowe w sprawy innego państwa także umowa o stacjonowaniu takich oddziałów w danym państwie. Tymczasem Putin w cytowanym wywiadzie z czerwca 2014 r. wyraźnie stwierdził, że: „Tak, rosyjskie wojska znajdowały się na Krymie zgodnie z międzynarodową umową o umiejscowieniu tam rosyjskiej bazy wojskowej. I rosyjskie wojska rzeczywiście pomogły mieszkańcom Krymu przeprowadzić referendum o swojej niepodległości i mieszkańcy zjednoczyli się z Federacja Rosyjską" ${ }^{\prime 2}$.

Podkreślić należy, że istnieje co najmniej kilka punktów zapalnych w państwach wchodzących swego czasu w skład ZSRR, wykorzystywanych przez Rosję jako forma nacisku wobec tych państw. Obok zajętego przez Rosję Krymu i toczącego się konfliktu w obwodzie donieckim i ługańskim stają się formą nacisku m.in. Naddniestrze (Mołdawia, ale też i ostatnio Ukraina), Abchazja i Osetia Południowa (Gruzja), a także Górski Karabach rozgrywany przez Rosję w konflikcie między Armenią i Azerbejdżanem. Nie ulega wątpliwości, że fatalne w skutkach było poparcie przez państwa zachodnie, bez wcześniejszych uzgodnień z Rosją

12 Интервью Владимира Путина... 
i wbrew woli Serbii, niepodległości Kosowa w lutym 2008 r., które stało się niebezpiecznym precedensem na przyszłość i wyraźnie było wykorzystane przez Rosję przy uznaniu przez nią w sierpniu 2008 r. niepodległości Południowej Osetii. Co prawda, Międzynarodowy Trybunał Sprawiedliwości (MTS) w Hadze uznał w swojej opinii doradczej z 22 lipca 2010 r., że ogłoszenie deklaracji niepodległości przez Kosowo nie naruszało prawa międzynarodowego, ale nie zmienia to faktu, że tak naprawdę to mocarstwa nadal rozgrywają swoje interesy kosztem słabszych państw ${ }^{13}$. Jak podkreślono w opinii doradczej MTS, „samo zadeklarowanie niepodległości nie może być niezgodne z prawem międzynarodowym, które nie przewiduje takiego ogólnego zakazu. Trybunał przypomniał, że znaczna część społeczności międzynarodowej - także państw, które poparły stanowisko serbskie w postępowaniu - w taki właśnie sposób uzyskała niepodległość. O podmiotowości państwa i zdolności do uczestnictwa w stosunkach międzynarodowych decyduje uznanie przez inne państwa, które jest aktem o charakterze politycznym"14.

Powyższe nie zmienia faktu, że każda taka interwencja rodzić może zagrożenie dla bezpieczeństwa regionalnego, a w konsekwencji także zagrożenie o szerszym zakresie. Dzisiaj wyraźna interwencja Rosji na obszarze wschodniej Ukrainy takie niebezpieczeństwo niesie, $\mathrm{w}$ tym również w odniesieniu do zagrożenia destabilizacji systemu polityczno-ekonomicznego Ukrainy. Jednocześnie, wbrew wielokrotnie powtarzanym przez Rosję twierdzeniom o zgodności jej działań na Ukrainie z prawem międzynarodowym, to naruszają one reguły prawa międzynarodowego i zobowiązania przyjęte przez Rosję.

Powstaje w związku z tym pytanie, jak mogą dochodzić swoich praw mniejszości narodowe w sytuacji, gdy pojawia się rzeczywiste lub potencjalne naruszenie tych praw. Współcześnie istnieją określone mechanizmy ochrony i dochodzenia praw mniejszości narodowych. Występują one zarówno w prawie wewnętrznym, jak i międzynarodowym. W przypadku Ukrainy w prawie ukraińskim obowiązują regulacje prawne spełniające standardy międzynarodowe $\mathrm{w}$ tym zakresie. Bardzo ważne są mechanizmy ochrony międzynarodowej zarówno na poziomie dwustronnym, jak i wielostronnym.

$\mathrm{Na}$ poziomie dwustronnym kwestie mniejszościowe zostały uregulowane w Umowie o przyjaźni, dobrym sąsiedztwie i współpracy między Ukrainą i Federacją Rosyjską z 31 maja 1997 r., w której ochronie praw mniejszości narodowych poświęcono art. $12^{15}$. Obie strony gwarantowały zamieszkałym na

${ }^{13}$ R. Kownacki, T. Żornaczuk, Opinia doradcza MTS $w$ sprawie deklaracji niepodległości Kosowa, „Biuletyn PISM”, 23.07.2010, nr 108 (716).

${ }^{14}$ Ibidem.

15 Договір про дружбу, співробітництво $і$ партнерство між Украӥною і Російською Федераиією, „Політика і час" 1997, № 7, http://zakon.nau.ua/doc/?code=643_006; Договор о дружбе, сотрудничестве и партнерстве между Российской Федераџией и Украиной, подписанныий в городе Киеве 31 мая 1997 г., http://www.akdi.ru/gd/proekt/077191GD.SHTM (28.11.2016). 
ich terytorium osobom należącym do mniejszości narodowych ochronę oraz rozwój etnicznej, kulturowej, językowej i religijnej tożsamości „bez jakichkolwiek działań asymilacyjnych wbrew ich woli”. Obie strony gwarantowały im także efektywne i rzeczywiste korzystanie z praw człowieka i podstawowych wolności „bez jakiejkolwiek dyskryminacji i w warunkach pełnej równości ustawowej". Podkreślano prawa oświatowe celem pełnego nauczania obu języków na swoim terytorium i przygotowania kadr pedagogicznych dla szkolnictwa w obu językach. Dodatkowo w art. 10 każda ze stron umowy gwarantowała obywatelom drugiej strony przebywającym na jej terytorium takie same prawa, jakie przyznawała własnym obywatelom, oprócz praw szczególnych wynikających z prawa wewnętrznego lub zobowiązań międzynarodowych. Każda ze stron zobowiązywała się również do prowadzenia polityki wobec własnych obywateli przebywających na terytorium drugiej strony zgodnie $\mathrm{z}$ dokumentami OBWE oraz z zasadami i standardami międzynarodowymi. W art. 11 określono natomiast przeciwdziałanie wszelkim zachowaniom, które mają na celu wywołanie waśni na tle narodowym, rasowym, etnicznym lub religijnym. Zarówno Rosja, jak i Ukraina są sygnatariuszami umów zawartych w ramach Organizacja Bezpieczeństwa i Współpracy w Europie oraz Rady Europy.

W systemie OBWE działalność prowadzi Wysoki Komisarz do Spraw Mniejszości Narodowych. Działa on na podstawie Dokumentu helsińskiego: wyzwania czasu przemian z 10 lipca 1992 r. ${ }^{16}$ Działający pod egidą Komitetu Wysokich Przedstawicieli (KWP) Wysoki Komisarz jest instytucją „wczesnego ostrzegania” $\mathrm{i}$ „wczesnego reagowania” $\mathrm{w}$ „możliwie najwcześniejszym stadium napięć dotyczących kwestii mniejszości narodowych". Działania swoje Wysoki Komisarz podejmował nie w każdym przypadku konfliktu, lecz w sytuacji, gdy istniejące napięcia mogły przerodzić się w konflikt w regionie OBWE, oddziałujący na pokój i stabilność lub stosunki między państwami, skutkujący jednocześnie koniecznością reakcji Rady i KWP. Mandat swój Wysoki Komisarz realizuje poufnie i niezależnie od stron bezpośrednio zaangażowanych w konflikt. Charakterystyczne jest też to, że mandat Wysokiego Komisarza nie upoważnia go do podejmowania działań w przypadku naruszenia praw człowieka (jednostki) - także w przypadku, gdy dana jednostka jest członkiem jakiejś mniejszości. Celem mandatu i działania Wysokiego Komisarza jest bowiem przede wszystkim zapobieganie konfliktom spowodowanym zamieszkiwaniem w państwie członkowskim OBWE mniejszości narodowych (narodowych, etnicznych, językowych, religijnych), a nie ochrona praw indywidualnych.

Istnieje również mechanizm kontrolny ludzkiego wymiaru OBWE realizowany także przez Wysokiego Komisarza. Powołany on został w efekcie Wiedeńskiego Spotkania KBWE (4 listopada 1986-19 stycznia 1989), a konkretnie na

${ }^{16}$ KBWE-Dokument Helsiński 1992: wyzwania czasu przemian, Warszawa 1992. 
podstawie przyjętego 19 stycznia 1989 r. Dokumentu końcowego ${ }^{17}$, zreformowanego na podstawie Dokumentu Kopenhaskiego z 1990 r. ${ }^{18}$ oraz Dokumentu Helsińskiego z 1992 r. Zmodyfikowany ustaleniami kolejnych spotkań mechanizm kontrolny obejmował ostatecznie następujące etapy postępowania:

- dobrowolną i obligatoryjną procedurę informacji;

- prawo państw trzecich do składania zażaleń i obowiązek udzielania odpowiedzi na te zażalenia;

- prawo do żądania negocjacji dwustronnych w sprawach ogólnych i konkretnych, dotyczących ludzkiego wymiaru OBWE;

- prawo każdego państwa do przedkładania na forum OBWE spraw zarówno po uprzednim użyciu procedury negocjacji dwustronnych, jak i niezależnie od niej;

- niepoufny charakter informacji przekazywanych w ramach systemu kontroli $^{19}$.

Drugim mechanizmem monitorująco-mediacyjnym w ramach OBWE była działalność ekspertów w zakresie praw człowieka; wskazane w pkt 43 Dokumentu Kopenhaskiego powoływanie ekspertów zostało doprecyzowane w trakcie obrad moskiewskich w 1991 r. w rozdz. I ust. 3-16 Dokumentu Końcowego Spotkania Moskiewskiego $^{20}$. W celu efektywnej realizacji ludzkiego wymiaru KBWE, określonego w pkt 1-4 Wiedeńskiego Dokumentu Końcowego z 1989 r., postanowiono stworzyć specjalny mechanizm monitorująco-mediacyjny w postaci ekspertów.

Kolejny system monitorująco-kontrolny został stworzony w ramach Rady Europy. Obejmuje on mechanizmy monitorująco-kontrolne w ramach dwóch konwencji: Europejskiej Karty języków regionalnych lub mniejszościowych, sporządzonej w Strasburgu 5 listopada 1992 r. ${ }^{21}$ oraz Konwencji Ramowej o ochronie mniejszości narodowych, sporządzonej w Strasburgu dnia 1 lutego 1995 r. $^{22}$

17 Abschließendes Dokument des Wiener Treffens 1986 der Vertreter der Teilnehmerstaaten der Konferenz über Sicherheit und Zusammenarbeit in Europa, welches auf der Grundlage der Bestimmungen der Schlussakte Betreffend die Folgen der Konferenz abgehalten wurde, Wien 1989, http://www.osce.org/documents/chronological.php (27.11.2016).

${ }_{18}$ Dokument des Kopenhagener Treffens der Konferenz über die menschliche Dimension der KSZE, Kopenhagen 29 Juni 1990, http://www.osce.org/documents/chronological.php (27.11.2016).

19 J. Menkes, A. Prystrom, Instytucjonalizacja ochrony praw człowieka w KBWE, ,Sprawy Międzynarodowe" 1992, nr 7-12, s. 40; A. Malicka, Ochrona mniejszości narodowych - standardy międzynarodowe i rozwiazania polskie, Wrocław 2004, s. 59.

${ }^{20}$ Dokument Moskiewskiego Spotkania Konferencji w sprawie Ludzkiego Wymiaru KBWE, [w:] Zbiór dokumentów, Warszawa 1992, nr 2.

${ }^{21}$ Europejska Karta języków regionalnych lub mniejszościowych, sporządzona w Strasburgu dnia 5 listopada 1992 r., „Dziennik Ustaw RP” 2009, nr 137, poz. 1121; Raport wyjaśniajacy do Europejskiej karty języków regionalnych lub mniejszościowych, [w:] Europejska karta języków regionalnych lub mniejszościowych: od teorii do praktyki. Materiaty z konferencji Warszawa 16-17 czerwca 2003 r., Warszawa 2004, s. 265 i n.

${ }^{22}$ Konwencja Ramowa o ochronie mniejszości narodowych, sporządzona w Strasburgu dnia 1 lutego 1995 r., „Dziennik Ustaw RP” 2002, nr 22, poz. 209; Raport wyjaśniający do Konwencji ra- 
Sygnatariuszem obu konwencji jest Ukraina ${ }^{23}$, która Kartę Języków ratyfikowała 19 września 2005 r., a Konwencję ramową już 26 stycznia 1998 r.

System monitoringu na podstawie Karty języków określony został w części IV Karty (art. 15-17). W ramach monitoringu wyróżnić można następujące jego elementy:

a) raporty państw składane do Sekretarza Generalnego RE;

b) badanie raportów przez Komitet Ekspertów z ewentualną wizytą zespołu eksperckiego w państwie ocenianym;

c) uwagi państwa do oceny dokonanej przez Komitet Ekspertów;

d) informacje dodatkowe przedkładane dla Komitetu Ekspertów przez mniejszości oraz organizacje pozarządowe;

e) przedłożenie końcowego sprawozdania przez Komitet Ekspertów, wraz z ewentualnymi uwagami państwa i informacjami od mniejszości oraz organizacji pozarządowych;

f) rekomendacja Komitetu Ministrów;

g) raport Sekretarza Generalnego Rady Europy z wykonania postanowień Karty języków składany Zgromadzeniu Parlamentarnemu co dwa lata;

Istotna jest tu zwłaszcza pozycja Komitetu Ekspertów określona w art. 17 Karty języków. Składa się z przedstawicieli państw (po jednym z każdego), które stały się stroną Karty języków. Członków Komitetu Ekspertów wyznacza Komitet Ministrów RE na podstawie propozycji przedkładanych przez każde państwo. Nominacja następuje na okres sześciu lat z możliwością ponownego powołania. Członkowie Komitetu są niezależni w swojej działalności i nie mogą otrzymywać żadnych wskazówek ze strony państwa, które ich desygnowało.

Podstawę działania Komitetu Ekspertów stanowi zatwierdzany przez sam Komitet regulamin prac. Pierwszy regulamin prac przyjęty został 29 czerwca $1998 \mathrm{r}$. i zmodyfikowany 1 grudnia 2000 r. na piątym posiedzeniu Komitetu ${ }^{24}$. Obowiązujący regulamin prac Komitetu Ekspertów przyjęty został w dniu 24 marca 2004 r. na 17. posiedzeniu Komitetu ${ }^{25}$. Zgodnie z regulaminem Komitet wybiera na dwuletnią kadencję przewodniczącego i jednego lub dwóch wiceprzewodniczących. Językiem obrad są angielski i francuski. W sprawach dotyczących państwa, z którego desygnowany został członek Komitetu, mógł on uczestniczyć w dyskusji, ale nie w głosowaniu w sprawie opinii. Także członek Komitetu nie uczestni-

mowej o ochronie mniejszości narodowych, [w:] Ratyfikacja przez Rzeczpospolita Polska Konwencji Ramowej Rady Europy o ochronie mniejszości narodowych, Warszawa 2006, s. 25 i n.

${ }^{23}$ Rosja jest sygnatariuszem tylko Konwencji ramowej.

${ }^{24}$ J.M. Woehrling, The European Charter for Regional or Minority Languages. A Critical Commentary, Strasbourg, November 2005, s. 258.

${ }^{25}$ Rules of Procedure of the Committee of Experts for the European Charter for Regional or Minority Languages (As amended by the Committee of Experts on 24 March 2004; MIN-LANG (2004) 8), http://www.coe.int/t/dg4/education/minlang/aboutcommittee/Rulesprocedure_en.pdf (27.11.2016). 
czy w wizytacji w państwie, które go desygnowało. W sprawach proceduralnych decyzje podejmowane są zwykłą większością głosów. W pozostałych sprawach Komitet podejmuje decyzje większością $2 / 3$ głosów. W przypadku, gdy w trakcie głosowania nad raportem państwa nie uda się uzyskać większości 2/3 głosów, stanowisko Komitetu Ekspertów przekazywane jest z uwzględnieniem opinii większości i mniejszości. Dokumenty robocze Komitetu, stanowiska członków zespołu wizytującego i inne dokumenty mają charakter poufny, chyba że Komitet podejmie inną decyzję w tej sprawie większością 2/3 głosów. Jawny charakter ma natomiast opinia końcowa Komitetu przedkładana państwu, a następnie Komitetowi Ministrów RE. W celu oceny raportu Komitet Ekspertów wyznacza jednego lub więcej sprawozdawców. Istnieje także możliwość odbycia w państwie bezpośredniej wizyty zespołu wizytującego utworzonego przez Komitet Ekspertów.

Obsługę prac Komitetu Ekspertów zapewnia Sekretarz Generalny RE, który także określa roczny budżet Komitetu Ekspertów na podstawie złożonych przez Komitet propozycji. Komitet Ekspertów w zakresie realizacji swoich zadań współpracuje z Komitetem Doradczym ustanowionym w Konwencji Ramowej.

W Raporcie wyjaśniającym do Karty wskazano jednoznacznie, że „system monitorowania nie ma charakteru procedury quasi-sądowej. Komitet Ekspertów posiada jedynie kompetencje $\mathrm{w}$ zakresie monitorowania realizacji postanowień Karty i zbierania informacji na ten temat. Instytucje, o których mowa w art. 16, nie mogą występować do Komitetu Ekspertów z wnioskiem o występowanie w roli podobnej do sądowego organu odwoławczego" (ust. 128).

Państwa zobowiązane są do złożenia raportów z wykonania przyjętych postanowień Karty języków. Pierwszy raport składany jest w ciągu roku od daty wejścia w życie postanowień Karty wobec danego państwa, a kolejne co trzy lata. Raporty opracowywane są w formie określonej przez Komitet Ministrów RE. Formę pierwszego raportu wstępnie określił Komitet Ekspertów na swoim pierwszym posiedzeniu 29 czerwca $1998 \mathrm{r}$. Zasady raportu pierwszego zostały zaakceptowane przez Komitet Ministrów RE na 648. posiedzeniu w dniu 10 listopada 1998 r. Zasady kolejnych raportów zostały także opracowane przez Komitet Ekspertów na posiedzeniu w dniu 7 lutego 2002 r. i zaakceptowane przez Komitet Ministrów ${ }^{26}$.

Raporty zawierają szereg szczegółowych informacji o mniejszościach narodowych i językach w państwie, polityce państwa, podstawach prawnych działalności mniejszości i ochrony języków, o realizacji przyjętych zobowiązań z Karty języków. Kolejne raporty zawierały także informację o implementacji rekomendacji Komitetu Ministrów RE - jeśli takowe zostały przyjęte.

Złożony przez dane państwo raport podlega ocenie przez Komitet Ekspertów. Komitet Ekspertów wyznacza sprawozdawcę lub sprawozdawców do tego

${ }^{26}$ J.M. Woehrling, The European Charter..., s. 247-249. 
raportu. Może także zwrócić się do państwa o uzupełnienie przedłożonych informacji. Prawo przekazywania informacji dla Komitetu mają organy państwa oraz stowarzyszenia działające wśród mniejszości lub w obszarze praw człowieka zarejestrowane w tym państwie. W art. 16 ust. 1 Karty jednoznacznie podkreślono, że „stowarzyszenia, legalnie ustanowione wewnątrz Strony, mogą zwracać uwagę komitetowi ekspertów na sprawy związane ze zobowiązaniami przyjętymi przez tę Stronę w myśl Części III niniejszej Karty. W Raporcie wyjaśniającym do Karty wyjaśniono, że celem tej zasady jest zapobieganie powstawaniu grup, których siedziba byłaby poza przedmiotowym państwem, stosujących postanowienia Karty, dotyczące systemu monitorowania, do waśnienia stron" (ust. 128) ${ }^{27}$.

Formalnie Komitet Ekspertów może poprzestać na weryfikacji tylko raportu i ewentualnie nadesłanych dodatkowych informacji oraz na tej podstawie opracować swoją opinię. Wypracowana opinia Komitetu Ekspertów przekazywana jest państwu, które złożyło raport. Komitet wyznacza jednocześnie termin do złożenia przez państwo swoich uwag do przekazanej opinii. Państwo może przyjąć opinię lub też złożyć we wskazanym terminie swoje uwagi. Brak reakcji państwa w wyznaczonym terminie uznawany jest za akceptację opinii Komitetu Ekspertów.

Po upływie wyznaczonego terminu opinia Komitetu Ekspertów, wraz z ewentualnymi uwagami państwa ocenianego, przekazywana jest do Komitetu Ministrów RE. Opinia Komitetu Ekspertów zawiera propozycje dla Komitetu Ministrów odnośnie do przygotowania indywidualnej rekomendacji dla danego państwa lub też rekomendacji dla większej liczby państw. Komitet Ministrów podejmuje decyzję o publikacji opinii Komitetu Ekspertów w całości lub części.

Po uzyskaniu opinii Komitetu Ekspertów, wraz z ewentualnymi sugestiami, Komitet Ministrów RE wydaje rekomendacje.

Co dwa lata Sekretarz Generalny RE składa Zgromadzeniu Parlamentarnemu sprawozdanie z realizacji postanowień Karty języków.

Upubliczniona dokumentacja z oceny raportów umieszczana jest na stronie internetowej Rady Europy ${ }^{28}$ i obejmuje: raport państwa, opinię Komitetu Ekspertów oraz rekomendację Komitetu Ministrów Rady Europy. Część państw złożyła już czwarty raport z realizacji postanowień Karty języków.

System monitoringu realizacji Konwencji ramowej został określony w art. 24-26 Konwencji. W ramach monitoringu wyróżnić można następujące jego elementy:

a) raporty państw składane do Sekretarza Generalnego RE,

b) ocena raportów przez Komitet Doradczy podjęta po wizytacji w państwie,

${ }^{27} \mathrm{~W}$ początkowym okresie istnienia systemu ochrony mniejszości w ramach Ligi Narodów skargi przeciwko Polsce składały podmioty działające poza obszarem Rzeczypospolitej - co powodowało sprzeciw Polski, a w efekcie doprowadziło do odrzucania takich skarg.

${ }^{28}$ European Charter for Regional or Minority Languages, http://www.coe.int/t/dg4/education/minlang/Report/default_en.asp (27.11.2016). 
c) uwagi państwa do oceny dokonanej przez Komitet Doradczy,

d) przedłożenie końcowego sprawozdania przez Komitet Doradczy wraz z ewentualnymi uwagami państwa i informacjami od mniejszości oraz organizacji pozarządowych,

e) rekomendacja Komitetu Ministrów,

Pozycja Komitetu Doradczego była zdecydowanie słabsza niż Komitetu Ekspertów. Wynikało to $\mathrm{z}$ faktu, że początkowo raporty miały być przekazywane przez Sekretarza Generalnego do Komitetu Ministrów RE, który przy ocenie raportów państw miał być tylko wspomagany przez Komitet Doradczy (art. 26 ust. 1 Konwencji ramowej oraz ust. 95 Raportu wyjaśniającego do Konwencji ramowej). Logiczne w takiej sytuacji było określenie opracowania regulaminu prac Komitetu Doradczego przez KMRE, a nie przez sam Komitet Doradczy (jak to ma miejsce w Komitecie Ekspertów) i, jak to określał Raport wyjaśniający do Konwencji ramowej, do zadań Komitetu Ministrów należało określanie „w ciągu jednego roku od wejścia w życie Konwencji ramowej, składu i reguł proceduralnych komitetu doradczego, którego członkami powinni być uznani eksperci w zakresie ochrony mniejszości narodowych" (ust. 96). Przed wejściem w życie Konwencji ramowej wypracowano jednak system wzmacniający pozycję Komitetu Doradczego.

Skład Komitetu Doradczego oraz ramowe określenie procedur jego działania zostały uregulowane rezolucją (1997)010 Komitetu Ministrów przyjętą w dniu 17 września 1997 r. na 601. posiedzeniu zastępców ministrów ${ }^{29}$. Wśród członków Komitetu Doradczego wyróżniono członków zwykłych i dodatkowych. Liczbę członków zwykłych określono na nie mniej niż 12, a nie więcej niż 18 powoływanych przez Komitet Ministrów. Wyboru dokonywano z listy kandydatów przedłożonej przez każde państwo, wobec którego weszły w życie postanowienia Konwencji ramowej; państwa przedkładały Sekretarzowi Generalnemu co najmniej po dwóch kandydatów dysponujących wiedzą ekspercką w zakresie ochrony mniejszości narodowych. Komitet Ministrów wybiera spośród nich jednego eksperta, kierując się kolejnością złożonych przez państwa list kandydatów aż do uzyskania maksymalnej liczby członków. Członkowie zwykli Komitetu Doradczego wybierani byli na jedną kadencję czteroletnią z możliwością tylko jednej reelekcji. Po zakończeniu kadencji dokonywano uzupełnienia składu, wyłaniając

${ }^{29}$ Resolution (1997) 010, Rules adopted by the Committee of Ministers on the Monitoring Arrangements under Articles 24 to 26 of the Framework Convention for the Protection of National Minorities (Adopted by the Committee of Ministers on 17 September 1997 at the 601 st meeting of the Ministers' Deputies) http://www.coe.int/t/dghl/monitoring/minorities/2_Monitoring/PDF_Resolution(1997)010_en.pdf_(27.11.2016). Por. The Rights of Minorities. A Commentary on the European Framework Convention for the Protection of National Minorities, ed. M. Weller, Oxford University Press, New York 2005, s. 578 i n.; P. Thornberry, M. Amor, M. Estébanez, Minority Rights in Europe: A Review of the Work and Standards of the Council of Europe, Council of Europe, Strasbourg 1994. s. 406 i n. 
kolejnych członków Komitetu Doradczego z list przedłożonych przez państwa w okresie późniejszym. W przypadku, gdy liczba państw zgłaszających kandydatów przekraczała liczbę wolnych miejsc w Komitecie Doradczym, dokonywano losowania między kandydatami, ustalając kolejność wejścia w skład Komitetu Doradczego. Komitet Ministrów, powołując członka zwykłego, określał czas jego kadencji.

Podobnie jak i w Komitecie Ekspertów, w którym przy ocenie raportu z państwa, desygnującego eksperta, mógł on uczestniczyć w dyskusji, ale nie uczestniczył w głosowaniu w sprawie opinii, w Komitecie Doradczym wprowadzono tę samą zasadę. Jednocześnie uwzględniając fakt, że liczba członków w Komitecie Doradczym będzie mniejsza niż państw sygnatariuszy Konwencji ramowejo, przewidziano także instytucję członka dodatkowego. Członek dodatkowy był wyłonionym z listy ekspertów przedstawicielem państwa oczekującym na wejście do Komitetu Doradczego. Swoją funkcję spełniał tylko w przypadku oceny raportu z państwa, które go desygnowało, uczestnicząc w posiedzeniu Komitetu Doradczego oraz w dyskusji, ale bez prawa udziału w głosowaniu nad przyjęciem opinii. Komitet Doradczy swoje pierwsze posiedzenie odbył w dniach 29 czerwca1 lipca 1998 r., podczas którego wypracowano projekt raportu pierwszego oraz wstępnie określono zasady regulaminu prac ${ }^{31}$

Szczegółowa procedura działania Komitetu Doradczego określona została w regulaminie prac przyjętym przez Komitet Doradczy 29 października 1998 r. oraz zatwierdzonym przez Komitet Ministrów w dniu 16 grudnia 1998 r. na 653. posiedzeniu zastępców ministrów ${ }^{32}$. Komitet wyłaniał ze swego składu na kadencję dwuletnią przewodniczącego oraz dwóch wiceprzewodniczących. Mogli być oni wybrani ponownie pod warunkiem, że druga ich kadencja mieściła się w kadencji, na którą zostali powołani do składu Komitetu Doradczego. Quorum zostało określone w składzie przekraczającym połowę jego członków zwykłych. Decyzje Komitet Doradczy podejmował zwykłą większością głosów. Generalnie przewidywano głosowanie jawne poprzez podniesienie ręki. Jednakże, w przypadku zgłoszenia wniosku o głosowanie tajne. jest ono przeprowadzone pod warunkiem poparcia wniosku przez 1/3 członków zwykłych. Dokonując

3030 kwietnia 2010 r. Konwencja ramowa obowiązywała 39 państw członkowskich Rady Europy.

${ }^{31}$ Advisory Committee on the Framework Convention for the Protection of National Minorities, Meeting Report; 1st meeting, 29 June-1 July 1998, Palais de l'Europe, Strasbourg ACFC/ MR/INF(1998)004, http://www.coe.int/t/dghl/monitoring/minorities/2_Monitoring/ACFCMeetingReports_en.asp (28.11.2016). Pod tym adresem dokumentacja z 28 posiedzeń; dokumentację z posiedzeń 29-33 można uzyskać za pośrednictwem Sekretariatu.

${ }^{32}$ Rules of Procedure of the Advisory Committee on the Framework Convention for the Protection of National Minorities (Adopted by the Advisory Committee on 29 October 1998), ACFC/ INF(1998)002, http://www.coe.int/t/dghl/monitoring/minorities/2_Monitoring/PDF_ACFC_RulesProcedure_en.pdf (28.11.2016). 
oceny raportu, Komitet Doradczy może skorzystać z opinii dodatkowych ekspertów, których powoływał. Za celową uznano współpracę z Komitetem Ekspertów i wzajemną wymianę informacji.

W przedmiotowej rezolucji (1997)010 określono również procedurę związaną z monitoringiem. Określono przede wszystkim kwestię kolejnych raportów. Wychodząc z przesłanki określonej w art. 25 ust. 1 Konwencji, że „każda Strona będzie przekazywać Sekretarzowi Generalnemu okresowo, i kiedykolwiek Komitet Ministrów o to poprosi, wszelkie inne informacje związane z realizacją niniejszej konwencji ramowej”, uznano, że celowe będzie systemowe rozwiązanie tej kwestii i wprowadzenie zasady periodyczności raportów, a kolejne raporty winny być składane po pięciu latach od złożenia pierwszego lub ostatniego raportu. Składanie kolejnych raportów zostało określone przez Komitet Ministrów 15 stycznia 2003 r. na 824. posiedzeniu zastępców ministrów, którzy decyzję swoją podjęli na podstawie projektu opracowanego przez Komitet Doradczy ${ }^{33}$. Składane Sekretarzowi Generalnemu raporty przekazywane były do Komitetu Ministrów. Komitet Ministrów przekazywał raport do oceny Komitetowi Doradczemu, który następnie przedkładał swoją ocenę raportu Komitetowi Ministrów. Komitet Doradczy miał prawo odbyć wizytację w państwie składającym raport, zwracać się o dodatkowe informacje do rządu tego państwa, pozyskiwać informacje od mniejszości narodowych oraz od organizacji pozarządowych. W praktyce powoływany jest kilkuosobowy zespół ekspertów przeprowadzający wizytację w państwie składającym raport, $w$ trakcie której mają miejsce spotykania z przedstawicielami organów publicznych, mniejszości narodowych, organizacji pozarządowych, ekspertami i naukowcami zajmującymi się sprawami mniejszości narodowych. Komitet Doradczy mógł zwrócić się do państwa składającego raport o złożenie uzupełnień lub dodatkowych informacji, które winny być przekazane nie później niż w ciągu 4 miesięcy. Aby zrealizować te zadania, Komitet Doradczy musiał uzyskać pełnomocnictwo Komitetu Ministrów. Za zgodą Komitetu Ministrów Komitet Doradczy mógł zwrócić się do państwa o złożenie raportu ad hoc.

Po analizie raportu oraz dodatkowych informacji, w tym uzyskanych w trakcie wizytacji w państwie składającym raport, Komitet Doradczy przedkładał Komitetowi Ministrów swoją opinię. Komitet Ministrów przyjmował zalecenia dla państwa oraz podejmował decyzję o upublicznieniu opinii. Upubliczniona dokumentacja z oceny raportów umieszczana jest także na stronie internetowej Rady Europy ${ }^{34}$.

33 Outline for State Reports to be submitted under the Second Monitoring Cycle, in conformity with Article 25 Paragraph 1 of the Framework Convention for the Protection of National Minorities, Adopted by the Committee of Ministers on 15 January 2003 at the 824th meeting of the Ministers' Deputies, ACFC/INF(2003)001 (http://www.coe.int/t/dghl/monitoring/minorities/2_monitoring/ PDF_2nd_cycle_Outline_en.pdf) (27.11.2016).

${ }^{34}$ Monitoring the implementation of the Framework Convention for the Protection of National Minorities, http://www.coe.int/en/web/minorities/monitoring (28.11.2016). 
Porównując status i strukturę oraz procedurę działania obu komitetów monitorujących: Komitetu Ekspertów i Komitetu Doradczego, widoczna jest mocniejsza pozycja konwencyjna i samodzielność działania Komitetu Ekspertów. Jednakże zarówno rekomendacje Zgromadzenia Parlamentarnego, jak i decyzje Komitetu Ministrów wyraźnie wzmocniły także pozycję faktyczną Komitetu Doradczego, zbliżając procedury monitoringu prowadzone na podstawie obu konwencji.

System monitoringu realizowany na podstawie Karty języków oraz Konwencji ramowej okazał się bardzo skuteczny w praktyce. Oba komitety monitorujące w swoich opiniach wyraźnie wykazywały dążenie do rozszerzania nie zawsze precyzyjnych uregulowań konwencyjnych. Dotyczyło to zwłaszcza działania Komitetu Doradczego. Skuteczność opinii obu Komitetów widoczna była w przypadku opóźniania, na prośbę zainteresowanego państwa, publikacji opinii Komitetu. Prośba taka była dyktowana zamiarem usunięcia wskazanych w opinii naruszeń praw mniejszości.

Omówione wyżej mechanizmy dochodzenia praw mniejszości narodowych lub językowych wskazują na działania, jakie mogą zostać wykonane także przez zainteresowane państwo, które uznaje, że związana z nim mniejszość jest dyskryminowana $\mathrm{w}$ innym państwie. Działania takie mogą zostać podjęte niezależnie od innych zabiegów dyplomatycznych. Niezależnie od zasadności kierowanych przez Rosję pod adresem Ukrainy oskarżeń o naruszenie praw mniejszości rosyjskiej to tych działań dyplomatycznych, a także określonych mechanizmami ochrony praw mniejszości Federacja Rosyjska nie podjęła.

\section{Bibliografia}

Abschließendes Dokument des Wiener Treffens 1986 der Vertreter der Teilnehmerstaaten der Konferenz über Sicherheit und Zusammenarbeit in Europa, welches auf der Grundlage der Bestimmungen der Schlussakte Betreffend die Folgen der Konferenz abgehalten wurde, Wien 1989, http://www.osce.org/documents/chronological.php (27.11.2016).

Advisory Committee on the Framework Convention for the Protection of National Minorities, Meeting Report; 1st meeting, 29 June-1 July 1998, Palais de l'Europe, Strasbourg ACFC/MR/INF(1998)004.

Dokument des Kopenhagener Treffens der Konferenz über die menschliche Dimension der KSZE, Kopenhagen 29 Juni 1990, http://www.osce.org/documents/chronological. php (27.11.2016).

Dokument Moskiewskiego Spotkania Konferencji w sprawie Ludzkiego Wymiaru KBWE, [w:] Zbiór dokumentów, Warszawa 1992, $\mathrm{nr} 2$.

European Charter for Regional or Minority Languages, http://www.coe.int/t/dg4/education/minlang/Report/default_en.asp (27.11.2016). 
Europejska Karta języków regionalnych lub mniejszościowych, sporządzona w Strasburgu dnia 5 listopada 1992 r., „Dziennik Ustaw RP” 2009, nr 137, poz. 1121.

Europejska karta języków regionalnych lub mniejszościowych: od teorii do praktyki. Materiały z konferencji Warszawa 16-17 czerwca 2003 r., Warszawa 2004.

General Comment No. 12: The right to self-determination of peoples (Art. 1), 13.03.84, http://www.unhchr.ch/tbs/doc.nsf/(Symbol)/f3c99406d528f37fc12563ed004960b4 ?Opendocument (27.11.2016).

Karta Narodów Zjednoczonych. Statut Międzynarodowego Trybunału Sprawiedliwości i Porozumienie ustanawiające Komisję Przygotowawcza Narodów Zjednoczonych, „Dziennik Ustaw” 1947, nr 23, poz. 90.

KBWE - Dokument Helsiński 1992: wyzwania czasu przemian, Warszawa 1992.

Konwencja Ramowa o ochronie mniejszości narodowych, sporządzona w Strasburgu dnia 1 lutego 1995 r., „Dziennik Ustaw RP” 2002, nr 22, poz. 209.

Kownacki R., Żornaczuk T., Opinia doradcza MTS w sprawie deklaracji niepodległości Kosowa, „Biuletyn PISM”, 23.07.2010, nr 108 (716).

Malicka A., Ochrona mniejszości narodowych - standardy międzynarodowe i rozwiąania polskie, Wrocław 2004.

Menkes J., Prystrom A., Instytucjonalizacja ochrony praw człowieka w KBWE, „Sprawy Międzynarodowe" 1992, nr 7-12.

Międzynarodowy Pakt Praw Obywatelskich i Politycznych otwarty do podpisu w Nowym Jorku dnia 19 grudnia 1966 r., „Dziennik Ustaw” 1977, nr 38, poz. 167 zał.

Monitoring the implementation of the Framework Convention for the Protection of National Minorities, http://www.coe.int/en/web/minorities/monitoring (28.11.2016).

Outline for State Reports to be submitted under the Second Monitoring Cycle, in conformity with Article 25 Paragraph 1 of the Framework Convention for the Protection of National Minorities, Adopted by the Committee of Ministers on 15 January 2003 at the 824th meeting of the Ministers' Deputies, ACFC/INF(2003)001, http://www. coe.int $/ \mathrm{t} / \mathrm{dghl} / \mathrm{monitoring} / \mathrm{minorities} / 2$ _monitoring/PDF_2nd_cycle_Outline_en.pdf (27.11.2016).

Raport wyjaśniający do Europejskiej karty języków regionalnych lub mniejszościowych, [w:] Europejska karta języków regionalnych lub mniejszościowych: od teorii do praktyki. Materiały z konferencji Warszawa 16-17 czerwca 2003 r., Warszawa 2004.

Raport wyjaśniajacy do Konwencji ramowej o ochronie mniejszości narodowych, [w:] Ratyfikacja przez Rzeczpospolita Polska Konwencji Ramowej Rady Europy o ochronie mniejszości narodowych, Warszawa 2006.

Resolution (1997) 010, Rules adopted by the Committee of Ministers on the Monitoring Arrangements under Articles 24 to 26 of the Framework Convention for the Protection of National Minorities (Adopted by the Committee of Ministers on 17 September 1997 at the 601st meeting of the Ministers' Deputies), http://www.coe. int/t/dghl/monitoring/minorities/2_Monitoring/PDF_Resolution(1997)010_en.pdf (27.11.2016).

Rules of Procedure of the Advisory Committee on the Framework Convention for the Protection of National Minorities (Adopted by the Advisory Committee on 29 October 1998), ACFC/INF(1998)002, http://www.coe.int/t/dghl/monitoring/minorities/2_ Monitoring/PDF_ACFC_RulesProcedure_en.pdf (28.11.2016). 
Rules of Procedure of the Committee of Experts for the European Charter for Regional or Minority Languages (As amended by the Committee of Experts on 24 March 2004; MIN-LANG (2004) 8), http://www.coe.int/t/dg4/education/minlang/aboutcommittee/ Rulesprocedure_en.pdf (27.11.2016).

The Rights of Minorities. A Commentary on the European Framework Convention for the Protection of National Minorities, ed. M. Weller, Oxford University Press, New York 2005.

Thornberry P., Amor M., Estébanez M., Minority Rights in Europe: A Review of the Work and Standards of the Council of Europe, Council of Europe, Strasbourg 1994.

Woehrling J. M., The European Charter for Regional or Minority Languages. A Critical Commentary, Strasbourg, November 2005.

Договір про дружбу, співробітниитво і партнерство між Украӥною і Російською Федеращією, „Політика і час” 1997, nr 7, http://zakon.nau.ua/doc/?code=643_006.

Договор о дружбе, сотрудничестве и партнерстве между Российской Федерачией и Украиной, подписанный в городе Киеве 31 мая 1997 г., http://www.akdi.ru/gd/ proekt/077191GD.SHTM (28.11.2016).

Закон України, Про засади державної мовної політики, „Відомості Верховної Ради” 2013, № 23, http://conventions.coe.int/Treaty/Commun/ChercheSig.asp?N$\mathrm{T}=148 \& \mathrm{CM}=8 \& \mathrm{DF}=\& \mathrm{CL}=\mathrm{ENG}(28.11 .2016)$.

Интервью Владимира Путина радио «Европа-1» и телеканалу TF1, http:/www. kremlin.ru/news/45832 (05.11.2014).

Конституція України, Відомості Верховної Ради Украӥни, (Із змінами, внесеними згідно із Законами), 1996, по. 30.

Федеральный конституцฺионный закон „О принятии в Российскую Федерацию Республики Крым и образовании в составе Российской Федерации новых субъектов - Республики Крым и города федерального значения Севастополя”, одобренному Государственной Думой 20 марта 2014 года, Советом Федерации 21 марта 2014 год. 
Гжегож Януш

\section{Региональная безопасность в контексте предполагаемого нарушения прав русского менышинства в Украине и механизмов европейской системы охраны прав национальных меньшинств}

Целью статьи является анализ международных правовых механизмов в сфере охраны прав национальных меньшинств, а также в сфере противостояния возможности нарушения региональной безопасности. Актуальность статьи связана с событиями и деятельностью, инициированными Россией на востоке Украины, также имеющими отношение к защите якобы нарушаемых прав русскоговорящих в Крыму и восточных областях Украины.

Кючевые слова: региональная безопасность, национальные меньшинства, Европа, Украина

$$
\text { Grzegorz Janusz }
$$

\section{Regional security in view of the alleged violation of the rights of Russians in Ukraine, in the context of the European system of minority rights protection}

The paper contains an analysis of international legal regulations of minority rights protection, as well as the mechanisms of prevention of regional security threats. The background of the analysis is the Russia-inspired and supported activity in the east of Ukraine, directed against the alleged violation of the rights of the Russian-speaking inhabitants of the Crimea and Ukraine's eastern districts.

Keywords: regional security, national minorities, Europe, Ukraine 